\title{
DEVELOPING A FRAMEWORK ON SUCCESS PERFORMANCE OF COMMUNITY BASED HOMESTAY TOURISM PROGRAMME: AN EVIDENCE FROM INSIDER OF HOMESTAY PERSPECTIVE
}

\author{
Nor Syuhada Zulkefli' ${ }^{1}$, Roslizawati Che Aziz ${ }^{2}$ \& Aifa Rozaini Mohd Radzol ${ }^{3}$ \\ ${ }^{1,2,3}$ Faculty of Hospitality, Tourism and Wellness, University Malaysia Kelantan \\ (syuhada.z@umk.edu.my, roslizawati@umk.edu.my)
}

\begin{abstract}
Community-Based Tourism (CBT) is an approach to tourism presumed to achieve the sustainable development goals (SDGs), especially involved on SDG1-No Poverty and SDG11-Sustainable Cities and Communities. In rural communities, homestays are essential CBT component that have made many contributions to the local economy and quality of life. The Malaysia Homestay Programme (MHP) has received special attention from the government due to its potential to enhance local communities' livelihoods and economic sustainability. This study assesses factors that measure the successful performance of communitybased tourism on the MHP. Homestay programmes are a form of community tourism, in which the host (operator) provides family-friendly stay facilities for rent to tourists, thus generating additional income for the family. Based on the previous studies, the homestay operators faced the following external challenges such as village landscape, inefficient networking, lack of cooperation and commitment from homestay operators, exploitation of external parties, as well as ineffective promotional and marketing activities. These challenges must be resolved effectively to sustain the MHPs forward momentum. Essentially, the experiences of hosts (homestay operators) in dealing with the above mentioned challenges should be sought and empirically documented for future policy-making activities by the development agencies and the society. The national economy is bound to progress with escalating arrivals of tourists if effective strategies are devised by the stakeholders in resolving the problems faced by the homestay operators. Prior studies have listed the critical factors that dictated the success or failure of CBT programmes from the stance of CBT managers and experts. Nonetheless, insights from the local community pertaining to the success of CBT have been largely ignored despite their significance. A case study approach was adopted in this research paper with a qualitative methodology. Data was collected from 17 key informants in 11 MHPs. A structured and in-depth interview was the primary data collection technique, used together with photos, note-taking, and sound recordings. From the interview analysis, 12 criteria were identified as most of the respondents had mentioned those criteria as success factors for MHPs. The findings also revealed 7 very important dimensions for MHP to receive high numbers of visitors which are: effective marketing and promotional strategies, maintained facilities and utilities, uniqueness and quality products/packages design, community engagement and support, collaboration and networking, leadership, and recognition, as well as previous awards. The new dimensions on homestay development identified in this study are recognition and previous awards, entrepreneurship and uniqueness of product and package design.

The study outcomes signify that most of the respondents claimed that the MHP success is dictated by the quantity of tourists. This is because; the volume of tourists generates additional income to those involved in the MHP. However, there are other dimensions that should be weighed in by homestay operators to ensure that their homestays can succeed and survive for a longer period and can be contribute to SDG1 and SDG11.
\end{abstract}

KEYWORDS: Malaysian Homestay Programme, Success Performance, Community-based tourism 


\section{PURPOSE AND BACKGROUND}

A popular tourism initiative that is considered consistent with tourism-based sustainable development is community-based tourism (CBT). CBT has been acknowledged as an excellent platform to initiate multiple activities that attract tourists to explore the available natural resources.

This tourism segment is a crucial economic tool that sustains cultural and natural attractions amidst foreign and local tourists. The evidence of the homestay programmes performance and success criteria are still hard to achieve much less progress on SDGs. Therefore, this study assesses the factors that measure the successful performance of community- based tourism on MHP.

\section{METHODOLOGY}

The case study approach was adopted in this qualitative research work. Data were gathered between June and July 2019 from 17 key informants in 11 MHPs; five community leaders, eight CBT operators, and four marketing staff. The selection of respondents was based on their availability and commitment to participate in the interview session and site visit. A structured and in-depth interview served as the primary data collection technique, along with photos, note-taking, and sound recording. The data were assessed using open coding by NVivo12.

\section{FINDINGS}

From the interview analysis, 11 criteria were identified as most of the respondents had mentioned those criteria as success factors for MHP. From these criteria, this study has broken the classifications into three groups. In the first group, the finding revealed 7 very important dimensions for MHP to receive high number of visitors which is: effective marketing and promotional strategies, maintained facilities and utilities, uniqueness and quality products/packages design, community engagement and support, collaboration, and networking, market environment, leadership and recognition, as well as previous awards.

In the second group, there were also three important dimensions derived from these criteria, namely organisational management skills, funding and human resources support and generating benefits for the community. In the third and last group, the new dimensions of homestay development identified in this study were: (a) recognition and previous awards, (b) entrepreneurship, and (c) uniqueness of product and package design.

\section{CONCLUSION}

The study outcomes signify that most of the respondents claimed that the MHPs success is dictated by the quantity of tourists. This is because; the volume of tourists generates additional income to those involved in the MHP.

However, there are other dimensions that should be weighed in by homestay operators to ensure that their homestays can succeed and survive for a longer period. These dimensions include provision of products, facilities, and services that are unique, efficient, well-maintained, safe, and satisfying; deployment of effective marketing technique including use of marketing networks; as well as acquiring and practicing skills and knowledge to operate the tourism businesses.

The community-based MHPs run by rural communities should be equipped with adequate experience, awareness, skills and knowledge to successfully operate the business. This is highlighted by the practice of the listed dimensions. 


\section{CONTRIBUTION/PRACTICAL IMPLICATIONS}

The MHPs reflect the rural entrepreneurship entities despite fitting the description of a CBT as outlined by Russell (2000). The programmes can also evolve into community-based business cooperatives. Thus, these dimensions serve as the basis to assess MHP performance, which can assist with enhancement decisions. It is hoped that this study will lead to new insights which will in turn be able to contribute to the success of the homestay programme especially with regard to increasing the economic and social status of the local community.

\section{REFERENCES}

Kayat, K., \& Zainuddin, N. F. A. (2016). Community-based tourism initiative in rural Malaysia: Is it a success? International Review of Management and Marketing, 6(S7), 242-249.

Kunjuraman, V., \& Hussin, R. (2017). Challenges of community-based homestay programme in Sabah, Malaysia: Hopeful or hopeless? Tourism Management Perspectives, 21, 1-9.

Pusiran, A. K., \& Xiao, H. (2013), Challenges and community development: A case study of Homestay in Malaysia. Asian Social Science, 9(5), 1-17. 